Acta Biol. Par., Curitiba, 30 (1, 2, 3, 4): 1-4. 2001.

\title{
Uma nova espécie de Anthidiinae parasita (Hymenoptera, Megachilidae) da Costa Rica ${ }^{1}$
}

\author{
A new species of parasitic \\ Anthidiinae (Hymenoptera, Megachilidae) \\ from Costa Rica ${ }^{1}$
}

DANÚNCIA URBAN ${ }^{2}$

Moure \& URBAN (1994) apresentaram uma chave para a identificação das seguintes espécies de Hoplostelis Dominique, 1898: Hoplostelis bivittata (Cresson, 1878) que ocorre do MÉXICO ao PANAMÁ; Hoplostelis cornuta (Bingham, 1897), de TRINIDAD, e Hoplostelis bilineolata (Spinola, 1841) de HONDURAS, GUIANAS, PERÚ E BRASIL. Tendo em mãos exemplares coletados na COSTA RICA, constatamos tratar-se de uma espécie nova, reconhecida à primeira vista pelas asas inteiramente tingidas com castanho. Nas espécies relacionadas acima as asas são claras, de um amarelo-méleo nos dois terços basais e tingidas com castanho no ápice.

${ }^{1}$ Contribuição no 1252 do Departamento de Zoologia, SCB, Universidade Federal do Paraná — Caixa Postal 19020 - 81531-990 Curitiba, Paraná, Brasil. ${ }^{2}$ Bolsista do CNPq. 


\section{Hoplostelis gabrieli sp. $\mathrm{n}$.}

(Figs 1 e 2)

DiAGNOSE - Cabeça com faixa amarela pós-ocelar prolongada atrás dos olhos quase até as mandíbulas; mesoscuto com duas máculas amarelas em U invertido e tergos com faixa basal amarela, exceto o segundo inteiramente preto.

HolóTIPO FÊMEA - Comprimento 9,08 mm; largura máxima da cabeça 3,72 mm; comprimento da asa a partir do esclerito costal 7,58 $\mathrm{mm}$. Tegumento predominante preto. Cabeça com os seguintes desenhos amarelos: nódoas ovaladas na base das mandíbulas; faixas paroculares largas, com estreitamento mediano e ultrapassando a tangente superior do ocelo mediano; duas estrias interalveolares incluindo as respectivas carenas, um pouco mais longas que a metade do comprimento do escapo; faixa pós-ocelar mais larga que o diâmetro dos ocelos continuando nas genas quase até a articulação das mandíbulas onde alarga em direção aos olhos. Antenas com escapo, pedicelo e flagelômero basal castanhos, restante enegrecido. Mesosoma preto com as seguintes áreas amarelas: duas grandes máculas em U invertido no mesoscuto (Fig. 1); axilas; margem do escutelo; pequena nódoa discal nos mesepisternos e outra pouco maior na parte dorsal dos metepisternos; nódoa alongada na face posterior dos fêmures anteriores e medianos, a nódoa muito curta nos anteriores; nódoa ovalada na face anterior dos fêmures posteriores, junto às tíbias. Tégulas enegrecidas; asas tingidas com castanho, $R$ enegrecida. Tergos pretos com faixa amarela, menos no segundo tergo, a do primeiro próxima à carena que separa a face anterior da face dorsal e notavelmente mais estreita que as demais; do terceiro ao sexto com faixa larga sendo a do terceiro a mais larga. Lados do quarto e quinto esternos com pequenas faixas amarelas, sexto esterno com a metade basal amarelo-escura.

Labro com duas projeções dentiformes junto ao clípeo; clípeo com tubérculo alongado médio-apical; mandíbulas alongadas, estreitando para o ápice, este com dois dentes angulosos separados dos dois basais por recorte côncavo menor que o recorte entre o dente basal e o sub-basal, e com tubérculo basal longo e carenado (Fig. 2).

Alótipo macho. Comprimento 9,0 mm; largura da cabeça 3,52 mm; comprimento da asa a partir do esclerito costal 7,58 $\mathrm{mm}$. Preto com desenhos amarelos. Mandíbulas amarelas orladas com enegrecido; clípeo com faixa distal amarela, projetada no disco em angulosidade; minúscula nó- 
doa amarela supraclipeal junto à sutura epistomal. Estrias paroculares, interalveolares e pós-ocelar como na fêmea. Escapo com pequena área castanho-pálida apical. Mesosoma e metasoma diferindo da fêmea pela ausência de mancha amarela nos metepisternos; ocorrência de manchas amarelas no segundo esterno e com faixa amarela distal no sétimo tergo.

Labro com duas protuberâncias basais pouco elevadas; clípeo com ápice elevado fracamente anguloso e mais largo no meio; mandíbulas com os flancos basais em lóbulos sobressaindo à borda do clípeo, distintamente menores que na fêmea.

HolótIPo FÊMEA - COSTA RICA, Heredia, Estación Biol. La Selva; $10^{\circ} 25^{\prime} \mathrm{N}, 84^{\circ} 0$ ’ W, 80m, 11.VI.1996. G. A. R. Melo leg. Alótipo macho e três parátipos fêmeas com os mesmos dados. No verso da etiqueta de procedência de todos os exemplares consta que emergiram de ninho de Euglossa Latreille, 1802. Depositados na Coleção de Entomologia Pe. J. S. Moure,Departamento de Zoologia, Universidade Federal do Paraná.

COMENTÁRIO - Na chave para a identificaçào de Moure \& URBAN (1994) entraria juntamente com Hoplostelis cornuta (Bingham, 1897) pelas máculas amarelas em U invertido do mesoscuto, que em $H$. cornuta sào unidas posteriormente. As mandíbulas dos machos destas duas espécies têm em comum um lóbulo basal, enquanto que em $H$. bivittata e $H$. bilineolata as mandíbulas não têm lóbulo basal.

$H$. cornuta é reconhecida pelas faixas amarelas largas em todos os tergos; as fêmeas de $H$. cornuta têm o dente sub-basal das mandíbulas amplamente separado do basal, aproximadamente no terço distal da margem cortante e a fronte quase inteiramente amarelo-ferrugínea. $\mathrm{H}$. gabrieli não tem faixa amarela no segundo tergo; as fêmeas têm o dente sub-basal das mandíbulas no meio da margem cortante.

Etimologia - O nome da espécie é homenagem ao coletor, Prof. Dr. Gabriel A. R. Melo do Departamento de Zoologia, Universidade Federal do Paraná.

\section{RESUMO}

É descrito um novo Anthidiinae parasita da Costa Rica, Hoplostelis gabrieli sp. n., reconhecido pelas asas inteiramente fuscas, faixa amarela estreita no tergo basal e pelo segundo tergo preto.

Palavras-chave: Hymenoptera, Apoidea, Megachilidae, Hoplostelis, taxonomia. 


\section{SUMMARY}

A new Anthidiinae parasite from Costa Rica, Hoplostelis gabrieli sp. $\mathrm{n}$., is described. It is recognized by the entirely fuscous wings, narrow yellow band on the first tergum and the entirely black second tergum.

Key words: Hymenoptera, Apoidea, Megachilidae, Hoplostelis, taxonomy.

\section{RÉSUMÉ}

On décrit un neuf Anthidiinae parasite collecte a Costa Rica, Hoplostelis gabrieli sp. n., reconnu par les ailes marrons, le première tergite avec une bande jaune et le seconde entièrement noir.

Mots CLÉs: Hymenoptera, Apoidea, Megachilidae, Hoplostelis, taxonomie.

\section{BIBLIOGRAFIA}

Moure, J. S. \& D. Urban, 1994. Rhynostelis, gen. n. e notas Hoplostelis Dominique (Hymenoptera, Apoidea, Megachilidae). Revta bras. Zool. 11 (2): 297-302.

Recebido em: 12 de janeiro de 2001. 